\title{
PENGEMBANGAN DESAIN DAN DIFERENSIASI PRODUK SEBAGAI KEUNGGULAN KOMPETITIF PADA BISNIS RITEL UMKM FURNITUR DAN AKSESORIS INTERIOR RUMAH
}

\author{
Titi Indahyani \\ Jurusan Desain Interior, School Of Design, BINUS University \\ Jln. K. H. Syahdan No. 9, Palmerah, Jakarta Barat 11480 \\ tindahyani@binus.edu
}

\begin{abstract}
Trade globalization caused the overwhelming of overseas products in the center of trades in Indonesia. The effect of this case was the small-scale and middle industries' products were difficult to compete with the impor one in Indonesia. The lack of product development strategy, lack of people's skils, technology, and dependence on the imported raw materials caused the limitation of stock production which was unique, creative, and innovative that became the competitve advantage of the UMKM. Based on these problems, a research to consider a strategy priority that was appropriate, effective, and efficient was conducted.
\end{abstract}

Keywords: design, strategic development, competitive advantage, furniture, home interior

\begin{abstract}
ABSTRAK
Globalisasi perdagangan menyebabkan banjirnya produk impor ke Indonesia, yaitu ke berbagai pusat grosir dan pusat perdagangan di sejumlah kota. Akibatnya, produk UMKM semakin sulit bersaing dengan produk impor sehingga pendapatan penjualan serta laba menurun drastis dan menghentikan usahanya. Belum optimalnya strategi pengembangan desain produk yang ada, terbatasnya ketrampilan SDM bagian produksi dan teknologi ditambah dengan kapasitas produksi yang terbatas serta ketergantungan yang relatif cukup tinggi terhadap bahan baku impor, menyebabkan ketersediaan stok produk UMKM yang unik, kreatif dan inovatif sebagai salah satu keunggulan kompetitif di bisnis ritel menjadi kurang stabil dan kurang dapat diandalkan terutama bagi pasar ritel yang bergerak sangat dinamis. Adanya beberapa permasalahan tersebut diatas melatarbelakangi dilakukannya perumusan strategi pengembangan desain yang tepat bagi UMKM untuk menjamin keberlanjutan usaha di masa depan serta perkembangan usaha kearah yang lebih baik khususnya di bisnis ritel furnitur dan aksesoris interior. Untuk itu diperlukan sebuah penelitian mengenai prioritas strategi apakah yang pantas, efektif \& efisien untuk digunakan dalam pengembangan desain UMKM pada bisnis ritel furnitur dan aksesoris interior rumah.
\end{abstract}

Kata kunci: desain, stategi pengembangan desain, mebel, interior rumah 


\section{PENDAHULUAN}

Belakangan ini pertumbuhan bisnis Usaha Mikro, Kecil dan Menengah (UMKM) menunjukkan gejala peningkatan termasuk di bidang bisnis furnitur dan aksesoris interior rumah (home acessories). Sejak tahun 2000 dunia usaha khususnya UMKM menunjukkan pertumbuhan secara signifikan. Jumlah unit usaha kecil meningkat 6,6\% dari 39,7 juta unit di tahun 1997 menjadi 42,32 juta unit di tahun 2003.

Berdasarkan data BisInfocus (2004) dinyatakan pula bahwa secara keseluruhan, peluang UMKM di Indonesia masih terbuka lebar baik untuk pasar lokal maupun ekspor. Produk UMKM telah merambah ke hampir seluruh negeri di dunia seperti Asia, Afrika, Timur Tengah, Amerika dan Eropa. Produk UMKM yang berbasis lokal dan memiliki karakteristik unik seperti kerajinan tangan dan furnitur memiliki daya saing kuat di pasar global dan merupakan produk unggulan di masa depan. Produk yang termasuk dalam funitur dan home acessories yang memiliki daya saing dan potensi besar untuk pasar ekspor tersebut antara lain: (1) kerajinan tangan, meliputi produk perak, tembaga, kayu, keramik, gerabah, batu alam, anyaman (rotan, serat alami, bambu), batik, sulaman/bordir, tenun ikat tradisional, sutera alam, dan lain-lain; dan (2) furnitur (modern dan antik), meliputi produk lemari, kursi makan, kursi tamu, kursi taman, gebyok, tempat tidur, ukiran kayu, dan lain-lain.

Menurut data Bisinfocus (2004), memasuki era globalisasi ekonomi, prospek yang cerah dari dunia usaha termasuk bisnis UMKM menghadapi tantangan yang berat untuk bersaing di pasar domestik maupun global. Globalisasi perdagangan telah menyebabkan banjirnya produk impor ke Indonesia secara legal maupun selundupan (ilegal) ke berbagai pusat grosir dan pusat perdagangan di sejumlah kota. Akibatnya, produk UMKM semakin sulit bersaing dengan produk impor sehingga, tidak sedikit industri kecil menengah yang penjualannya anjlok dan menghentikan usahanya. Dalam upaya menanggulangi hal tersebut, salah satu upaya yang dilakukan Pemerintah adalah mengutamakan pemberdayaan usaha mikro, kecil, dan menengah sebagai salah satu penggerak perekonomian nasional. Dalam konteks ekonomi nasional, usaha mikro, kecil dan menengah mempunyai peran strategis penting yang disebabkan beberapa hal diantaranya bersifat fleksibel untuk masuk dan keluar, membutuhkan sumberdaya baik kualitas maupun kuantitas (modal, teknologi, bahan baku, tingkat pendidikan, dan tingkat keterampilan) yang relatif kecil serta penyerapan tenaga kerja yang besar.

Di balik cerahnya prospek bisnis UMKM di bidang seni, desain dan kerajinan ini, timbul persaingan yang sangat ketat antara lain dari segi desain, diversifikasi produk, kualitas hasil produk, pemasaran serta pengembangan usaha walaupun pasar dalam negeri dan luar negeri masih terbuka luas. Sebagai contoh adalah bisnis ritel furnitur dan aksesoris interior rumah sudah mulai banyak diproduksi oleh kalangan UMKM termasuk usaha mikro dan kecil termasuk dari kalangan pengusaha/wirausahawan yang lebih terdidik. Pengusaha/wirausahawan yang lebih terdidik dalam hal ini adalah pengusaha yang mempunyai latar belakang pendidikan yang lebih tinggi dari umumnya pengusaha tradisional yang cenderung hanya mengandalkan ketrampilan yang turun temurun namun kurang diimbangi pendididkan formal. Namun sayangnya, selama ini usaha yang dijalankan belum memberikan keuntungan optimal karena adanya beberapa keterbatasan, antara lain: keterbatasan pengetahuan akan seni dan desain, konsep pengembangan desain produk, modal, saluran distribusi, pemilihan supplier, SDM berkualitas, merchandising, manajemen operasional serta pengembangan bisnis.

Masih banyak pebisnis ritel UMKM termasuk dari kalangan lebih terdidik tersebut masih belum memiliki ketrampilan mengeskplorasi seni dan desain yang memadai guna menghasilkan beragam variasi produk yang kreatif, inovatif dan kompetitif namun memenuhi selera pasar. 
Produk furnitur dan akesoris interior rumah yang berasal dari UMKM terkadang masih mengandalkan rancangan desain maupun pola yang berasal dari bentuk-bentuk yang sudah ada seperti meniru atau hanya sedikit melakukan modifikasi serta membuat produk hanya berdasarkan desain sesuai pesanan dari pelanggan saja. Bahkan masih banyak pula yang menerapkan cara "coba dan salah" (trial \& error) sehingga proses pengembangan desain menjadi terhambat baik dari segi waktu dan biaya.

Dengan berkembangnya wawasan pengetahuan akan ragam variasi produk serta kolaborasi berbagai pihak terkait, diharapkan bisnis ritel UMKM furnitur dan home acessories dapat lebih kompetitif dalam menghadapi persaingan pasar lokal dan internasional.

\section{METODE}

Metode penelitian yang digunakan dalam penulisan ini adalah dalam bentuk deskriptif dengan mempelajari masalah yang terjadi di beberapa pengusaha UMKM furnitur dan home acessories sehingga akan dapat diperoleh gambaran, informasi, penjelasan, dan kondisi yang berkaitan dengan obyek penulisan pada saat sekarang serta gambaran mengenai sifat suatu keadaan yang tengah berlangsung pada saat penelitian dilaksanakan termasuk memeriksa sebab-sebab dari suatu gejala tertentu.

\section{HASIL DAN PEMBAHASAN}

Berdasarkan pengamatan ke berbagai perusahaan, bisnis furnitur dan aksesoris interior rumah (home acessories) merupakan suatu bisnis yang dapat dikatakan tidaklah sederhana. Bisnis ini merupakan suatu paduan antara bisnis konsultan, kontraktor dan ritel. Bagi pebisnis /pengusaha yang mulanya bergerak di konsultan ataupun pelaksana interior (kontraktor) maka usaha ritel merupakan bentuk pengembangan usaha yang diperlukan sebagai salah satu upaya perusahaan dalam mempertahankan keberadaannya di era yang sangat kompetitif terlebih pada saat krisis. Dengan usaha bisnis ritel maka calon pemakai jasa/klien (client) ataupun pelanggan (customer) dapat bertemu dengan para konsultan dan kontraktor, melihat serta membeli secara langsung hasil karya mereka di ruang pamer/toko (showroom) ritel. Keberadaan toko ini sangat membantu pengusaha dalam mendapatkan aliran arus kas tunai (cash flow) harian secara berkesinambungan dan dapat membiayai aktivitas operasional bagi divisi konsultan maupun kontraktor yang umumnya mendapatkan dana dari klien berdasarkan periode pembayaran dalam suatu waktu tertentu (term of payment).

Dengan adanya toko/bisnis ritel, pengusaha furnitur dan home acessories akan mendapatkan pekerjaan mulai dari skala kecil secara langsung dari klien maupun dari pelanggan yang datang berkunjung, misalnya pekerjaan pembuatan rak sepatu, penggantian kain kursi makan, pembuatan tirai kamar, renovasi kamar mandi dan lain-lain. Pekerjaan kecil ini bila ditangani dengan serius akan menghasilkan pendapatan usaha yang cukup signifikan bagi perusahaan. Sedangkan bagi pengusaha yang awal mulanya langsung bergerak di usaha bisnis ritel interior, maka adanya divisi konsultan dan kontraktor dapat menambah pendapatan usaha secara signifikan. Pendapatan usaha yang didapat dari pekerjaan konsultan dan kontraktor berupa proyek perencanaan maupun pelaksanaan interior, furnitur maupun pengadaan home acessories dengan nilai yang umumnya sangat signifikan bagi perusahaan. Dengan demikian maka bila toko sedang dalam keadaan sepi pengunjung terutama di hari, bulan ataupun waktu tertentu maka adanya proyek interior dengan jangka waktu pendek maupun panjang akan sangat membantu naiknya pendapatan usaha dan laba perusahaan secara keseluruhan sehingga dapat menutupi minimnya pendapatan dan laba toko di periode waktu tertentu. 
Bisnis ritel furniture dan home acessories baik internasional maupun nasional saat ini cenderung dijalankan dengan visi dan misi antara lain menjadi "one stop shopping center" yang menjual berbagai jenis kategori produk furnitur dan aksesoris interior rumah berkualitas dengan harga terjangkau dan kompetitif. Beberapa perusahaan ritel internasional di bidang furnitur dan aksesoris interior rumah yang menerapkan sistem ini antara lain Ikea, Wal-Mart's, Direct Buy, Index, Ace Hardware, Home Builders Center, Carrefour, Lotte Mart dan Pongs Home.

Dalam kaitannya dengan keberlanjutan usaha di masa depan, para peritel tersebut sangat peduli terhadap kesejahteraan para stakeholder dengan meningkatkan nilai atau value dalam menjalankan bisnis yang dapat berdampak positif terhadap sektor ekonomi, sosial dan lingkungan. Dalam upayanya tersebut, para peritel berusaha memberikan pelayanan yang memuaskan terhadap pelanggan selama berbelanja baik dari segi ketersediaan berbagai fasilitas dan variasi produk yang lengkap, dari sisi pelayanan penjualan dan terhadap pengembangan kualitas sumber daya manusia. Dengan sumber daya manusia yang berkualitas maka pelayanan terhadap pelanggan menjadi semakin baik dan dapat menjadi nilai tambah bagi perusahaan tersebut. Dalam upaya mendukung keterjangkauan harga, hubungan dengan para pemasok (supplier) pun dipererat terutama dengan para pemasok yang berdomisili disekitar toko. Dengan bekerjasama dengan para local supplier maka jalur transportasi barang menjadi lebih pendek sehingga biaya dapat ditekan. Para peritel juga mampu meyakinkan para supplier untuk memberikan harga yang sangat kompetitif melalui pemesanan barang dalam jumlah banyak bagi seluruh cabang toko yang tersebar diberbagai daerah.

\section{Kondisi Variasi Pemilihan Produk di Gerai/Toko}

Seiring meningkatnya pembangunan properti serta daya beli masyarakat terhadap properti baru dengan harga relatif terjangkau khususnya di bangunan apartemen maupun rumah susun sederhana, para peritel kelas dunia turut merambah ke Indonesia terutama ke berbagai penjuru kota Jakarta serta ke berbagai kalangan masyarakat untuk meraih peluang pasar yang terbuka luas. Carrefour, Index, Ace Hadware, Lotte Mart dan Pongs Home merupakan beberapa peritel internasional yang telah memanfaatkan peluang pasar ini. Variasi produk yang ditawarkan peritel internasional besar ini sangat beragam, mulai dari furnitur, aksesoris interior rumah termasuk soft furnishings sampai perlengkapan rumah tangga lainnya. Produk-produk tersebut dibeberapa toko ritel besar tertentu dipamerkan dalam bentuk contoh (mock up) suatu ruang interior, seperti ruang keluarga, ruang tidur dan dapur lengkap dengan aksesoris interior rumah yang sesuai dengan mock up ruang tersebut. Dengan demikian diharapkan pelanggan dapat membeli tidak hanya furnitur namun tertarik juga untuk membeli aksesoris interior rumah seperti yang dipamerkan pada mock up ruang tersebut. Seperti terlihat pada mock up ruang tidur anak dan ruang keluarga (Gambar 1 dan 2) pada showroom IKEA.

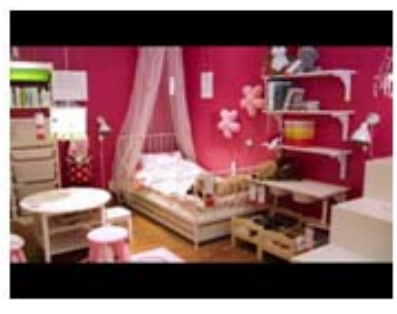

Gambar 1 Mock up ruang tidur anak

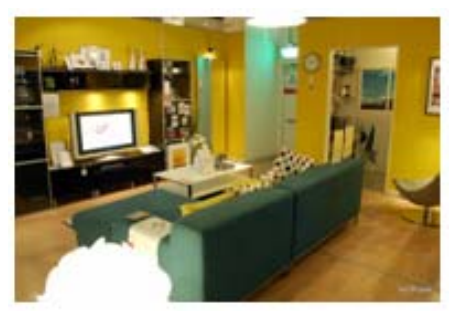

Gambar 2 Mock up ruang keluarga

Beberapa merek produk furnitur (branded furniture) dan aksesoris interior rumah terkenal dari berbagai negara pun turut membuka perwakilannya di Jakarta, antara lain Baker Furniture, Alessi, Kare, dan lain-lain. Brand ini umumnya diperuntukkan bagi kalangan atas dengan harga yang tergolong di atas rata-rata. Berdasarkan data dari The Jakarta Post (2012), walaupun hanya memiliki 
pangsa pasar yang sangat terbatas yaitu sekitar 2\%, namun mengingat besarnya jumlah penduduk Indonesia, maka peluang pasar bagi kalangan ini masih sangat menjanjikan. Top branded furniture lainnya yang sekarang ada di pasaran antara lain Carpel, Cassina, Gasperini dan Da Vinci dari Italy, Keilnauer dari Canada, Extensis dari Australia dan FlexiStyle dari Amerika. Sedangkan dari Spanyol antara lain: Vidal Grau, Zaragoza, Movi, Mariner dan Vincente.

Beberapa tahun belakangan ini perusahaan ritel nasional dengan merek furnitur yang cukup kuat, turut ambil bagian pula dalam aktivitas ini antara lain Vinoti, Vivere, Columbia, Herman Dexter, Moie, Hadiprana Accent, Vinoti Living, Floral Home, Milenia, Chantique dan lainnya._Namun sayangnya, koleksi produk terutama home accessories termasuk soft funishings umumnya belum secara optimal memanfatkan produksi lokal dan masih mengimpor dari negara tetangga seperti Cina, Thailand, India, Vietnam, Philipina maupun negara lainnya. yang telah memiliki desain produk dengan variasi yang sangat banyak dan dalam jumlah/stok yang cukup banyak._Hal ini dapat disebabkan oleh beberapa alasan. Pertama, peritel nasional ini masih terfokus pada produksi funitur semata dan masih mengandalkan dominasi produk impor bagi koleksi produk home accessories yang ditawarkan kepada para pelanggan di gerai/toko/showroom mereka. Kedua,_adanya pengusaha yang melihat peluang bahwa tidak banyak toko furnitur dan aksesoris interior rumah yang menawarkan konsep toko yang menjual produk dari berbagai negara sehingga mereka memutuskan untuk memilih dan membeli produk home accessories dengan produk impor. Ketiga, pemilihan produk impor "terpaksa” dilakukan antara lain untuk memenuhi tingginya permintaan akan produk yang unik, berkualitas dengan perputaran desain yang sangat cepat namun kapasitas produksi yang tinggi. Sedangkan produk lokal dianggap masih belum mampu mengimbangi hal ini. Keempat, harga produk impor yang relatif lebih kompetitif terutama bila dibeli dalam jumlah besar. Pengusaha umumnya mengambil resiko pembelian dalam jumlah besar namun dengan pertimbangan bahwa pergerakan (turn over) barang yang cukup cepat yang ditunjang pula oleh desain yang unik dan kreatif.

Dalam hal ini seyogyanya pengusaha lokal skala UMKM dapat lebih mengoptimalkan eksistensinya untuk dapat memanfaatkan peluang pasar dengan memenuhi kebutuhan pengusaha ritel kelas menengah maupun besar lainnya serta masyarakat Indonesia yang sudah semakin meningkat kesadarannya untuk lebih mencintai produk lokal. Dengan lebih berperan sertanya pengusaha UMKM maka diharapkan pembelian produk impor oleh para peritel dapat dialihkan sebagian ke dalam negeri yang tentunya akan berdampak meningkatnya kesejahteraan UMKM.

\section{Perencanaan Barang dan Diferensiasi Produk}

Menurut Latief Institute (2001), salah satu hal penting dalam membangun keunggulan kompetitif yang harus dijaga oleh peritel untuk jangka panjang yaitu pelanggan yang loyal. Artinya komitmen pelanggan untuk berbelanja di suatu toko karena pelanggan menyukai toko tersebut, antara lain dengan membangun loyalitas pelanggan melalui positioning, customer service dan merchandise. Di bisnis ritel, produk yang merupakan barang yang dijual, disebut merchandise. Perencanaan barang dalam hal ini memegang peranan yang penting saat perusahaan mengimplementasikan strategi pengembangan produk atau diversifikasi. Apa pun kebijakan barang yang dipilih tidak boleh meninggalkan aspirasi pelanggan. Produk yang unik adalah salah satu hal yang penting dalam aktivitas diferensiasi produk. Menurut Astuti (2004:415,423), dalam industri yang kompetitif, kunci untuk mendapatkan keunggulan kompetitif adalah diferensiasi produk. Suatu penawaran pasar dapat didiferensiasi dengan lima dimensi, yaitu produk (bentuk, fitur, kualitas kinerja, kualitas kesesuaian, keawetan, kehandalan, kemampuan perbaikan, style dan rancangan), jasa (kemudahan pesan, pengiriman, pemasangan, pelatihan pelanggan, konsultasi pelanggan, maintenance dan repair, miscellaneous services), personil, saluran dan citra (simbol, media, iklim dan kejadian).

Astuti (2004) berpendapat bahwa suatu diferensiasi bermakna jika memenuhi kriteria antara lain: penting (memberikan manfaat yang sangat bernilai bagi sejumlah pembeli), berbeda, unggul, 
tidak mudah ditiru pesaing, pembeli berkemampuan untuk membayar perbedaan yang ada (affordable), menguntungkan dengan mengenalkan perbedaan tersebut (profitable). Sedangkan Triyono (2006), menyatakan bahwa beberapa hal yang masuk dalam dimensi produk antara lain adalah model atau gaya dan keragaman barang yang dijual mengacu pada pilihan akan jenis dan jumlah barang.

Saat ini peritel UMKM masih belum mengoptimalkan diferensiasi produk melalui produk yang unik sebagai penunjang keunggulan kompetitif. Terkadang produk yang ditawarkan hanya meniru dan memodifikasi dari produk yang sudah ada dipasaran atau bahkan hanya berdasarkan permintaan dari pembeli saja. Sedangkan keberagaman produk yang dipasarkan masih terbatas karena umumnya banyak pengusaha UMKM menjalankan beberapa aktivitas usahanya secara mulifungsi sehingga proses pengembangan desain produk serta pemilihan barang/produk menjadi kurang optimal.

\section{Pengembangan Desain dan Inovasi Produk UMKM}

Bagi pengusaha UMKM yang kreatif, pengembangan desain produk yang ada sekarang selalu diusahakan berubah seiring dengan perkembangan tren, material dan teknologi. Diferensiasi produk telah dianggap komponen penting di dalam perusahaan tersebut sehingga inovasi produkpun dapat terus tumbuh dan berkembang. Strategi diferensiasi telah diyakini oleh pelaku bisnis ritel di bidang ini sebagai suatu kekuatan untuk mampu melawan pesaingnya dan merebut pangsa pasar yang lebih luas. Perbedaan yang dibuat harus memenuhi beberapa kriteria yaitu: penting, unik, unggul, dapat dikomunikasikan, mendahului dan terjangkau, sehingga mampu menciptakan suatu posisi kompetitif yang berarti dan berbeda dalam benak pelanggan sasarannya.

Kemampuan membuat sesuatu yang unik tentu erat kaitannya dengan kreativitas. Sebenarnya perajin Indonesia secara kesehariannya telah memiliki sifat kreatif dan artistik yang didapat secara turun temurun dari nenek moyang kita dahulu. Kemampuan seni budaya ini merupakan potensi yang dapat diasah terus untuk menunjang pengembangan industri kerajinan nasional menjadi internasional. Dengan demikian potensi untuk pengembangan desain dan inovasi produk lokal yang bercitarasa maupun berkelas internasional menjadi sesuatu produk yang unik dan memenuhi persyaratan pemasaran tertentu tentunya sangat berpeluang besar untuk lebih dioptimalkan lagi hasil pencapaiannya. Rudy Ch Lengkong (2010), Ketua ASEPHI, berpendapat bahwa produk-produk kerajinan tangan Indonesia memiliki keunggulan antara lain : inovatif, bermutu tinggi dan memiliki keanekaragaman bahan baku yang tidak dimiliki negara produsen pesaing seperti Cina. Dengan dimanfaatkannya bahan baku lokal secara maksimal maka produk lokal tidak memerlukan bahan baku impor sehingga harga jual produk tidak akan terpengaruh oleh nilai dolar yang fluktuatif. Dengan keunggulan-keunggulan itu, sebenarnya produk kerajinan tangan Indonesia tidak perlu khawatir kalah bersaing dengan produk-produk luar negeri, seperti Thailand, Malaysia, dan China.

Beberapa UMKM telah menerapkan pengembangan desain, kreatifitas dan inovasi produk bercita rasa internasional dimulai dari sejak awal berdirinya usaha tersebut misalnya dengan membuat desain yang selalu memadukan unsur tradisional Indonesia dengan unsur etnik bercita rasa internasional. Sebagai contoh adalah kursi antik dari daerah Jawa Tengah menggunakan kain pelapis kursi yang diimpor dari Srilanka,bahan baku tas, alas makan, alas meja dan furnitur dan aksesoris interior lainnya didesain menggunakan material alam olahan dari daun pandan, akar wangi dan lainlain (Gambar 3 dan 4). 


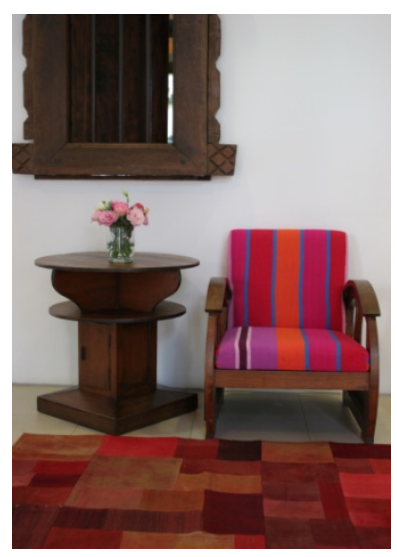

Gambar 3 Kursi sedan (Koleksi Temple Trees)

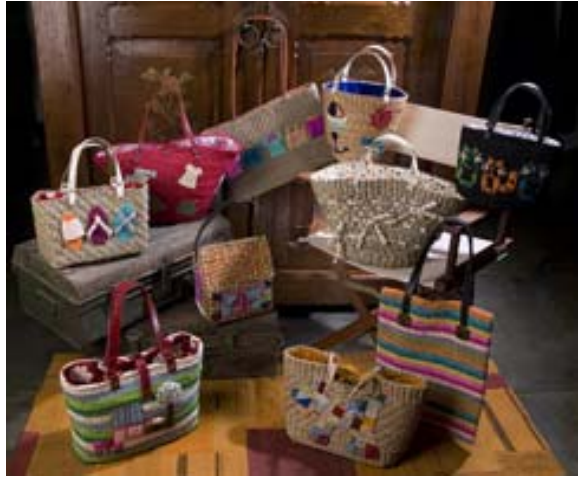

Gambar 4 Karpet dan tas dari beragam material (koleksi Temple Trees)

Pengembangan desain produk juga sudah berusaha mengikuti tren pasar antara lain sudah ada kategori rangkaian produk ramah lngkungan yang terbuat dari limbah kain. Dalam hal pengembangan produk, dapat dikatakan bahwa beberapa UMKM telah mencoba memenuhi tuntutan pasar lokal dan internasional antara lain menyediakan produk dengan desain lintas budaya (cross culture), produk dengan desain yang ramah lingkungan (green design) serta adanya kepedulian kepada lingkungan sosial seperti orang utan dengan memberi donasi kepada Yayasan terkait untuk setiap pembelian produk tertentu. Dengan demikian diharakan produk menjadi lebih memiliki nilai (value) dimata pelanggan.

\section{Kualitas dan Nilai (Value) Produk yang Baik}

Astuti (2004) menyatakan bahwa "Produk akan sukses jika memberikan nilai dan kepuasan kepada pembeli sasaran". "Kepuasan akan dirasakan oleh pelanggan apabila persepsi kinerja produk atau jasa yang diterimanya (dari pembelian produk atau jasa) dirasakan sama besar atau lebih besar dibandingkan dengan harapannya".

Di bisnis ritel, produk yang merupakan barang yang dijual, disebut merchandise. Triyono (2006) berpendapat bahwa ada tiga hal yang masuk dalam dimensi produk, yaitu: intensitas (produktivitas barang yang dijual), model atau gaya (jenis barang yang dijual) dan keragaman barang. Sedangkan nilai barang yang dijual (value) memiliki tiga dimensi, yaitu : nilai yang berkaitan dengan harga yang ditawarkan dibandingkan dengan persaingan yang ada, kualitas yang mengacu pada hubungan antara harga, kualitas dan posisi toko ritel tersebut di pasar serta tingkat harga. Astuti (2004) berpendapat bahwa produk adalah apapun yang ditawarkan ke suatu pasar untuk memenuhi kebutuhan atau keinginan manusia. Sedangkan berkaitan dengan nilai, ada lima jenjang nilai dalam konsepsi produk yang disebut hierarki nilai pelanggan. Tiap jenjang akan menambah nilai kepada pelanggan. Pertama adalah inti produk (manfaat dasar yang dibeli pelanggan). Kedua, produk dasar (mengubah manfaat inti ke dalam produk dasar). Ketiga, produk yang diharapkan (kesatuan atribut dan kondisi yang sebenarnya diharapkan pembeli ketika membeli produk). Keempat, produk yang disempurnakan (melebihi harapan pelanggan. Kelima, produk potensial (mencakup semua kemungkinan penyempurnaan dan transformasi produk di masa yang akan datang).

Sebagai ilustrasi pencapaian tahapan jenjang tersebut di atas antara lain dengan usaha yang telah dilakukan oleh beberapa UMKM, melalui produk kursi kayu. Nilai (value) yang didapat pelanggan secara berjenjang adalah sebagai berikut: pelanggan dapat membeli kursi kayu bergaya etnik Asia di toko salah satu UMKM yang nyaman bagi keluarga. Tersedia beragam pilihan kursi kayu yang dapat dilapisi dengan kain etnik Asia yang bervariasi sesuai pilihan pelanggan. Pelanggan akan mendapat bonus dua buah bantal kursi yang terbuat dari limbah kain bila membeli langsung dua buah 
kursi, karena dengan membeli kursi kayu etnik ini, pelanggan mendukung gerakan "Go Green: Reduce, Reuse, Recycle” yang di canangkan dunia Internasional. Kursi kayu ini merupakan kursi lama /semi antik yang didapat dari desa-desa di Jawa Tengah namun kurang dihargai sebagai barang bernilai seni oleh penduduk setempat. Sedangkan citra (image) produk perusahaan melalui merek/brand yang dimiliki UMKM akan semakin menambah tinggi nilai produk bagi pelanggan. Terlebih bila citra produk UMKM tersebut adalah produk lokal kualitas ekspor dengan desain unik khas etnik Asia. Sehingga banyak pelanggan yang dengan bangga memakai produk tersebut di kesehariannya, layaknya produk bermerek terkenal lainnya.

\section{SIMPULAN}

Pengembangan desain dan diferensiasi produk dapat dioptimalkan dalam bisnis ritel UMKM yang berkelanjutan di masa mendatang sebagai keunggulan kompetitif yang memenuhi kebutuhan pasar khususnya di bisnis ritel furnitur dan aksesoris interior rumah (home accessories) yang sangat dinamis. Namun adanya keterbatasan pengetahuan para UMKM akan desain yang baik, unik, memiliki ciri khas/karakter merupakan beberapa kendala dari banyak kendala lainnya yang menyebabkan ketersediaan produk di level UMKM menjadi kurang stabil dan kurang dapat diandalkan serta dikhawatirkan kurang dapat bersaing di pasaran domestik dan global yang mengakibatkan terhambatnya pengembangan bisnis yang berkelanjutan di masa mendatang. Di samping itu pengembangan desain dari para UMKM belum mampu mengimbangi kecepatan perputaran bisnis ritel furnitur dan aksesoris interior yang dinamis dan secara periodik jangka pendek selalu membutuhkan produk unik/khas yang baru. Di saat meningkatnya kondisi kesadaran masyarakat untuk lebih memilih dan memakai produk lokal serta besarnya peluang pasar yang ada, ternyata saat ini produk lokal masih relatif dianggap kurang mampu secara optimal memenuhi kebutuhan bisnis ini yang sangat sensitif terhadap desain, kualitas, kapasitas produksi dan biaya produksi karena akan berpengaruh terhadap harga jual kepada pelanggan maupun dalam menghadapai persaingan yang ketat antar usaha sejenis. Beberapa kendala yang umumnya dihadapi oleh pengusaha ritel maupun UMKM di bisnis ini antara lain, cepatnya peniruan produk oleh pesaing, kurangnya pasokan produk dengan desain yang unik dan khas yang tersedia di pasaran lokal, terbatasnya kapasitas bengkel (workshop) dan sumber daya manusia terlatih, yang dapat berakibat pada minimnya pengembangan desain, diferensiasi dan diversifikasi produk. Pengembangan desain, diferensiasi dan diversifikasi produk yang ditunjang kualitas serta memiliki nilai (value), dapat dijadikan sebagai keunggulan kompetitif bagi UMKM yang berkelanjutan di masa depan.

\section{DAFTAR PUSTAKA}

Astuti, S. W. (2004). Manajemen pemasaran. Jakarta: Universitas Terbuka.

Bisinfocus. (2004). Profil usaha kecil dan menengah di Indonesia. Tangerang: Bisinfocus Data Pratama.

David, F. R. (2009). Manajemen strategis. Jakarta: Salemba Empat.

Deputi Bidang Pemasaran Dan Jaringan Usaha Kementerian Koperasi dan UKM. (2006). Buku proceeding: Bursa kemitraan workshop dan temu bisnis.

Latief Institute. (2001). Buku panduan: Pelatihan manajemen bisnis ritel. Jakarta: Yayasan A. Latief.

Triyono, S. (2006). Sukses terpadu bisnis ritel. Jakarta: Elex Media Komputindo. 